\title{
Molecular evidence for the aquarium origin of the green alga Caulerpa taxifolia introduced to the Mediterranean Sea
}

\author{
O. Jousson ${ }^{1,2, *}$, J. Pawlowski ${ }^{1,3}$, L. Zaninetti ${ }^{1}$, A. Meinesz ${ }^{4}$, C. F. Boudouresque ${ }^{2}$ \\ 'Département de Zoologie et Biologie animale, Université de Genève, $\mathrm{CH}-1224$ Chêne-Bougeries/Genève, Switzerland \\ ${ }^{2}$ Centre d'Océanologie de Marseille, UMR CNRS 6540, F-13288 Marseille, France \\ ${ }^{3}$ Muséum d'Histoire Naturelle, CH-1211 Genève 6, Switzerland
}

${ }^{4}$ Laboratoire Environnement Marin Littoral, Université de Nice-Sophia Antipolis, Parc Valrose, F-06108 Nice Cedex 2, France

\begin{abstract}
Here, we present the first molecular evidence that the tropical green alga Caulerpa taxifolia, which is quickly spreading in the Mediterranean and out-competing native species, escaped to the sea from a public or private aquarium. Our data show that this alga is genetically identical to the strain cultivated in western European aquaria since the early 1970s. The facility with which this strain is obtained world-wide represents a potental danger of additional biological invasions.
\end{abstract}

KEY WORDS: Caulerpa taxifolia Mediterranean A Aquaria ITS IDNA

\section{INTRODUCTION}

The genus Caulerpa (Ulvophyceae) comprises about 70 species ubiquitous in coastal marine environments. One of these species, C. taxifolia (Vahl) C. Agardh, is common in tropical seas and has been reported along the Atlantic American coast (from Brazil to the Caribbean), in the African Atlantic (Gulf of Guinea), the Indian Ocean and the Pacific Ocean (Taylor 1977 Meinesz \& Boudouresque 1996). Since the early 1970 s. a strain assigned to this species, of unknown geographical origin, has been cultured to be used as a natural display in the tropical marine aquarium of the Wilhelma Zoologischbotanischer Garten (Stuttgart, Germany). Between 1980 and 1983, this strain was given to the tropical aquarium of Nancy (Northern France) and subsequently to the aquarium of Monaco, located on the Mediterranean shore (Meinesz \& Boudouresque 1996). As a rapidly growing and decorative alga, it is particularly appreciated by aquariophiles (Artaut 1987).

\footnotetext{
·E-mail: jousson2@sc2a.unige.ch
}

In the mid-1980s, an alga similar to the Caulerpa taxifolia strain cultivated in public aquaria was observed for the first time in the Mediterranean Sea, off the coast of Monaco (Meinesz \& Hesse 1991). Since then, the species has rapidly spread in the Northwestern Mediterranean, invading most of the sublittoral environments and competing with native benthic species (Verlaque \& Fritayre 1994, Villèle \& Verlaque 1995, Bellan-Santini et al. 1996, Bartoli \& Boudouresque 1997). Spectacular progression of this alga was observed on the French and Italian Riviera, where the affected areas increased from $1 \mathrm{~m}^{2}$ in 1984 to 3 ha in 1990 and 3000 ha in 1996 (Meinesz et al. 1997). Isolated colonies were also discovered in French Catalonia (1991), Tuscany, the Balearic Islands (1992), Sicily (1993), and Croatia (1994) (Meinesz \& Boudouresque 1996) (Fig. 1), possibly resulting from vegetative dissemination by pleasure boats and/or fishing nets (Sant et al. 1996). Morphological, ecological and physiological studies have demonstrated that the Mediterranean C. taxifolia differs from known tropical populations, exhibiting larger size, vigorous growth and resistance to low temperatures (Meinesz et al. 1995. Komatsu et 
al. 1997). Its competitive success has also been attributed to a number of other factors such as a lack of severe nutrient limitation, heterotrophy, and the production of toxic and/or repellent secondary metabolites (Guerriero et al. 1993, Boudouresque et al. 1996. Chisholm et al. 1996, Delgado et al. 1996, Lemée et al. 1996, Pesando et al. 1996, Boudouresque 1997, Chisholm \& Jaubert 1997). It has been proposed that $C$. taxifolia was accidentally released into the Mediterranean from a public aquarium (Meinesz \& Hesse 1991, Meinesz \& Boudouresque 1996). Alternatively, the alga may have originated from a Caulerpa species (identified as $C$. mexicana Sonder ex Kützing) that migrated through the Suez Canal from the Red Sea to the Eastern Mediterranean, and then to the Western Mediterranean (Chisholm et al. 1995).

In order to test the hypothesis of an aquarium origin for the Mediterranean Caulerpa taxifolia, we analysed the ribosomal DNA sequences from isolates of $C$. taxifolia obtained from several public aquaria and compared them to the algae collected in different localities of the Mediterranean. Additionally, we analysed rDNA sequences of a number of tropical populations of $C$. taxifolia as well as other species of the genus Caulerpa, including 3 populations of $C$. mexicana, of which the possible delineation from $C$. taxifolia remains controversial (Taylor 1977, Coppejans \& Prud'homme van Reine 1992, Meinesz et al. 1994, Chisholm et al. 1995, Meinesz \& Boudouresque 1996). In the present study, the internal transcribed spacer (ITS) rDNA was chosen as an appropriate marker to distinguish between spe- cies belonging to the Ulvophyceae (Bakker et al. 1995, Leskinen \& Pamilo 1997) and to examine the intraspecific variations in Caulerpa (Pillman et al. 1997).

\section{MATERIALS AND METHODS}

DNA extraction, PCR amplification, cloning and sequencing. Living specimens of 10 Mediterranean populations, 5 aquarium isolates and 3 tropical populations of Caulerpa taxifolia were isolated, together with 6 specimens belonging to 4 other Caulerpa species ( $C$. mexicana, C. prolifera [Forsskål] Lamouroux, C. racemosa [Forsskål] J Agardh and C. sertularioides [Gmelin] Howe), between November 1997 and February 1998 (Table 1). DNA was extracted in guanidine lysis buffer, precipitated with isopropanol and dissolved in distilled water. PCR amplifications were performed in a total volume of $50 \mu \mathrm{l}$ with an amplification profile consisting of 40 cycles of $30 \mathrm{~s}$ at $94^{\circ} \mathrm{C}, 30 \mathrm{~s}$ at $52^{\circ} \mathrm{C}$ and $120 \mathrm{~s}$ at $72^{\circ} \mathrm{C}$, followed by $5 \mathrm{~min}$ at $72^{\circ} \mathrm{C}$ for final extension. The ITS rDNA region was amplified using a Caulerpa-specific primer located near the $3^{\prime}$ end of the $18 \mathrm{~S}$ rDNA (5'-CCTCTGAACCTTCGGGAG $\left.-3^{\prime}\right)$ and a universal primer located near the $5^{\prime}$ end of the 28 S rDNA (5'-TTCACTCGCCATTACT-3'). Amplified PCR products were purified using the High Pure PCR Purification Kit (Boehringer), and were subsequently either sequenced directly or after cloning (3 clones for each $C$. taxifolia specimen), using the ABI 377 automatic sequencer (Perkin Elmer).

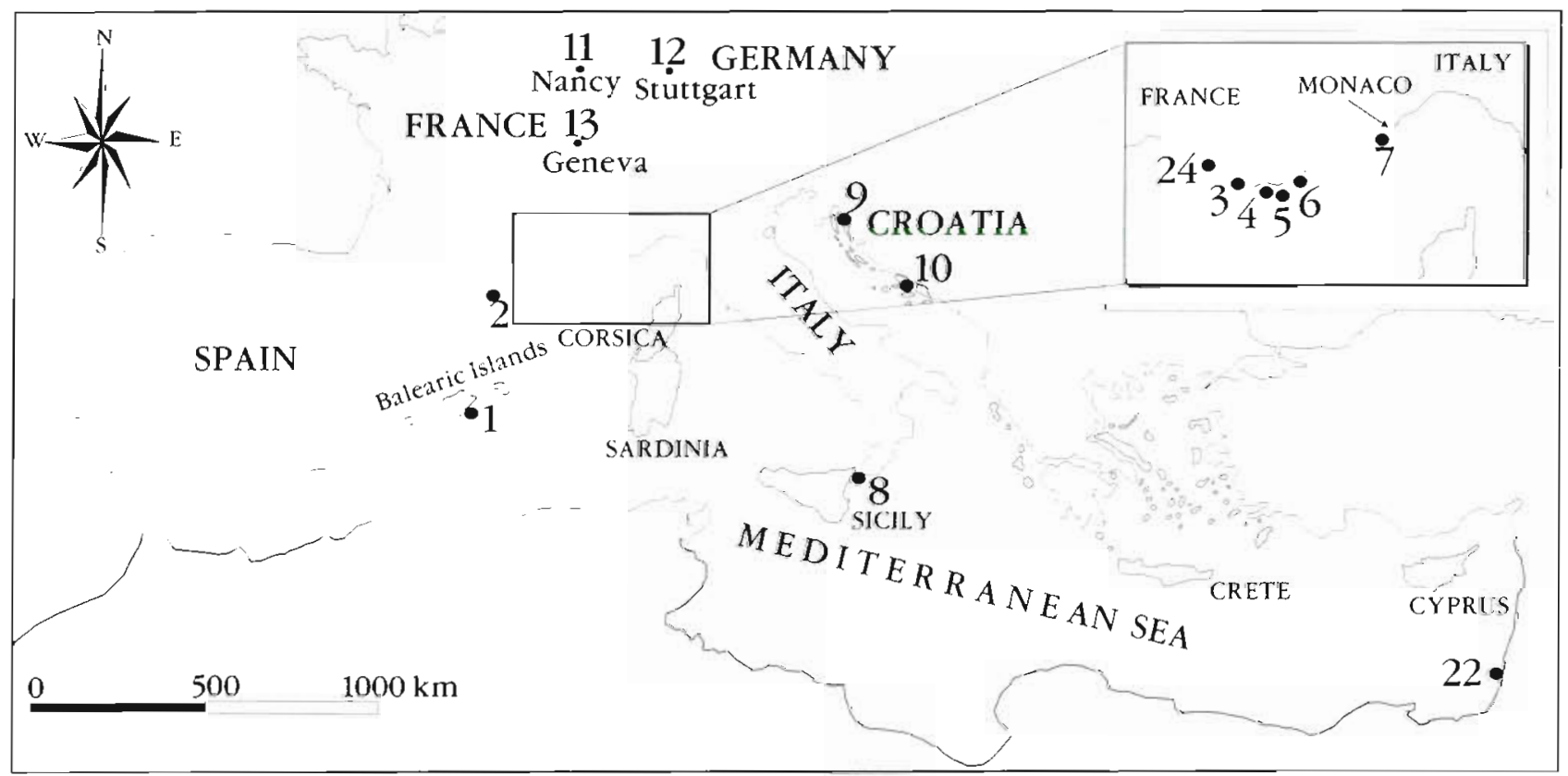

Fig. 1. Geographical map of studied Caulerpa from European aquaria and the Mediterranean 
Table 1. Analysed material: Caulerpa species, geographical ongin and collector

\begin{tabular}{|c|c|c|c|}
\hline $\begin{array}{l}\text { Specimen } \\
\text { number }\end{array}$ & Species & Locality & Collector \\
\hline 1 & C. taxifolia & Majorca, Balearic I., Spain & A. Meinesz \\
\hline 2 & C. taxifolia & Saint-Cyprien, French Catalonia & J. de Vaugelas \\
\hline 3 & C. taxifolia & Le Brusc, Provence, France & V. Gravez \\
\hline 4 & C. taxifolia & Toulon, Provence, France & A. Meinesz \\
\hline 5 & C. taxifolia & Port-Cros I., Provence, France & J. M. Cottalorda \\
\hline 6 & C. taxifolia & Le Lavandou, Provence, France & A. Meinesz \\
\hline 7 & C. taxifolia & Villefranche, French Riviera & L. Burtaire \\
\hline 8 & C. taxifolia & Messina, Sicily, Italy & C. Orestano \\
\hline 9 & C. taxifolia & Krk I., Malinska, Croatia & A. Meinesz \\
\hline 10 & C. taxifolia & Hvar I., Starigrad, Croatia & A. Meinesz \\
\hline 11 & C. taxifolia & Nancy aquarium, France & B. Condé \\
\hline 12 & C. taxifolia & Stuttgart aquarium, Germany & Mrs Koch \\
\hline 13 & C. taxifolia & Geneva aquarium shop, Switzerland & O. Jousson \\
\hline 14 & C. taxifolia & Enoshima aquarium, Japan & T. Komatsu \\
\hline 15 & C. taxifolia & Oahu aquarium, Hawaii, USA & P. Amade \\
\hline 16 & C. taxifolia & Guadeloupe I., Caribbean & J. Blachier \\
\hline 17 & C. taxifolia & Martinique I., Caribbean & J. Blachier \\
\hline 18 & C. taxifolia & Ryu-Kyu I., Japan & T. Komatsu \\
\hline 19 & C. prolifera & Martinique I., Caribbean & J. Blachier \\
\hline 20 & C. sertularioides & Martinique I., Caribbean & J. Blachier \\
\hline 21 & C. mexicana & Jedda, Red Sea, Saudi Arabia & A. Meinesz \\
\hline 22 & C. mexicana & Stot-Yam, Israel, Mediterranean & M. Fine \\
\hline 23 & C. mexicana & Martinique I., Caribbean & J. Blachier \\
\hline 24 & C. racemosa & Marseille, Provence, France & S. Ruitton \\
\hline
\end{tabular}

Sequence analysis. The sequences were manually aligned using the GDE 2.2. (Larsen et al. 1993) and analysed using the following methods: the neighborjoining (NJ) method (Saitou \& Nei 1987), the maximum parsimony (MP) method, using the heuristic search option included in PAUP 3.1.1 (Swofford 1993), and the maximum likelihood (ML) method using the fast DNAml program (Olsen et al. 1994). The reliability of internal branches in the NJ and MP trees was assessed using the bootstrap method (Felsenstein 1988). The Phylo-win program (Galtier \& Gouy 1996) was used for distance computations, NJ and ML tree building and bootstrapping.

\section{RESULTS}

The aligned data set of ITS1, 5.8S and ITS2 rDNA consisted of 665 sites, including 86 variable and 48 parsimony informative positions. The phylogenetic analysis of Caulerpa ITS sequences using different phylogenetic methods generated similar results (Fig. 2). Comparison of sequences revealed the presence of a striking similarity between all of the Mediterranean and aquarium C. taxifolia. Very few insertions or deletions were observed between specimens, and no nucleotide substitutions were revealed. Such sequence similarity contrasts with the high divergence observed among the tropical specimens of $C$. taxifolia, which can attain values of up to $7.3 \%$. The interspecific sequence divergence within Caulerpa ranges from 9 to $14 \%$. The aquarium and Mediterranean specimens of $C$. taxifolia appear to be closely related to their Caribbean counterparts $(100 \%$ bootstrap support). In contrast, the single Indo-Pacific specimen of $C$. taxifolia branches as a sister group to the aquarium-MediterraneanCaribbean clade. Direct sequencing of PCR products was only possible for the aquarium and Mediterranean specimens of $C$. taxifolia. For the tropical C. taxifolia and the other Caulerpa species examined, sequencing of several cloned PCR products showed ITS rDNA polymorphism within all specimens. The sequence divergence within a given individual, null for aquarium and Mediterranean C. taxifolia, ranges from $0.5 \%$ in tropical C. taxifolia specimens to $3.7 \%$ in C. racemosa.

\section{DISCUSSION}

The ITS rDNA sequence identity of all aquarium and Mediterranean specimens of Caulerpa taxifolia is consistent with the hypothesis that all these specimens form a single strain. Furthermore, the lack of ITS poly- 


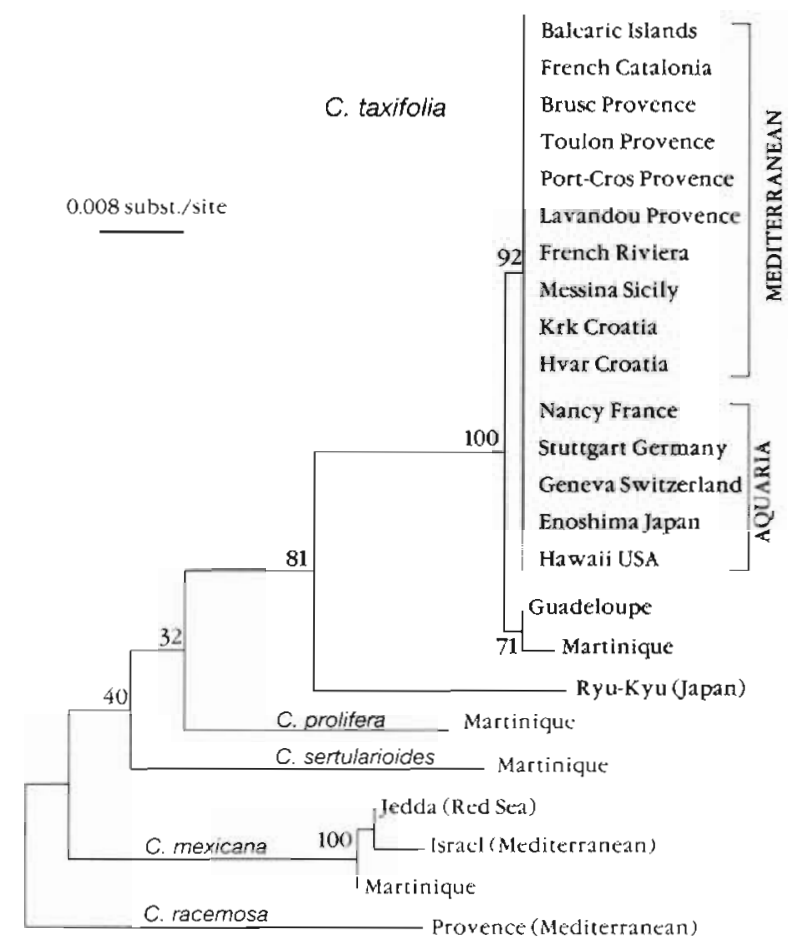

Fig. 2. Maximum likelihood tree of Caulerpa spp. inferred from ITS rDNA sequences. Numbers at nodes are percentages of 100 bootstrap replicates. The same tree topology was obtained using neighbor-joining and maximum parsimony phylogenetic methods

morphism provides an additional argument to support the hypothesis that we are dealing with a population comprising few individuals which has undergone prolonged confinement under aquarium conditions. Indeed, such isolation could be responsible for the complete homogenization of ribosomal DNA, in agreement with the observed loss of heterogeneity in laboratory stocks (Linares et al. 1994). The sequencehomogenization mechanisms of multigenic families, referred to as concerted evolution, have been observed both in sexual (Schlotterer \& Tautz 1994) and parthenogenetic lineages (Hillis et al. 1991). Complete sexual reproduction has never been observed in $C$. taxifolia in either aquaria or the Mediterranean; as a matter of fact, only male gametes have been reported (Meinesz \& Boudouresque 1996). This would suggest that the aquarium-Mediterranean strain of $C$. taxifolia represents a clone. Despite their unusual morphological and physiological characteristics, aquarium and Mediterranean specimens of C. taxifolia branch within the tropical $C$. taxifolia group. It can be noted that the C. taxifolia group is clearly distinct from related species of the section Filicoidae, $C$. sertularioides and $C$. mexicana. Our results show that none of the studied specimens of $C$. mexicana appears to be related to the aquarium-Mediterranean C. taxifolia, invalidating the hypothesis of Chisholm et al. (1995), who tentatively derived Mediterranean C. taxifolia from Eastern Mediterranean $C$. mexicana in order to support a Red Sea origin of the former. Phylogenetic analysis demonstrates, with $100 \%$ bootstrap support, that the aquarium-Mediterranean strain of $C$. taxifolia is related to the Caribbean populations. However, accurate identification of its origin necessitates the study of populations covering the entire geographical range of C. taxifolia.

\section{CONCLUSIONS}

Our results confirm that the Caulerpa species which is invading the Mediterranean belongs to $C$. taxifolia and originates from an aquarium strain accidentally introduced to the sea. This is consistent with the fact that C. taxifolia was cultivated in a Northern European public aquarium long before its first appearance in the Mediterranean. Further support for this hypothesis is provided by the fact that this alga was then introduced to a number of aquaria, including one present on the Mediterranean coast, just before being actually observed in the sea, off of this aquarium. The biological invasions resulting from species introduction are today a cause of growing concern. In the marine environment, several vectors of introduction have been suggested: transport on ship hulls by fouling and clinging, ballast waters, deliberate introductions for aquaculture purposes and unintentional introductions associated with aquaculture practices (Carlton \& Geller 1993, Ribera \& Boudouresque 1995, Carlton 1996). In addition, a few introduced species are suspected to have escaped from aquaria (Russell 1992). The case of C. taxifolia described here is the first demonstration of the introduction of an aquarium selected species. As the aquarium-Mediterranean strain of $C$. taxifolia is appreciated as an ornamental, robust, and fast growing seaweed, it can be purchased in many aquarium shops and is actuaily present world-wide in a number of public and private aquaria. This represents a potential danger, as aquarium specimens of $C$. taxifolia may be accidentally released into other seas (see also Gillespie et al. 1997). Given the potentially invasive character of the aquarium-Mediterranean strain of $C$. taxifolia, it would appear that a stricter control of its sale is warranted.

Acknowledgements. This study was supported by the European Community (Life-DGXI: Control of the spread of Caulerpa taxifolia in the Mediterranean'), the French Ministère de l'Environnement and the Swiss National Science Foundation. We thank all collectors (see names in Table 1) for field assistance and 3 anonymous reviewers for helpful com- 
ments. The nucleotide sequences analysed in this study have been deposited in the EMBL/GenBank database (accession numbers: AJ228960 to AJ228999).

\section{LITERATURE CITED}

Artaut J (1987) Dites-le avec des algues. Aquarium Mag 26: $39-42$

Bakker FT, Olsen JL, Stam WT (1995) Evolution of nuclear rDNA ITS sequences in the Cladophora albida/sericea clade. J Mol Evol 40(6):640-651

Bartoli P, Boudouresque CF (1997) Transmission failure of parasites (Digenea) in sites colonized by the recently introduced invasive alga Caulerpa taxifolia. Mar Ecol Prog Ser 154:253-260

Bellan-Santini D, Arnaud PM, Bellan G, Verlaque M (1996) The influence of the introduced tropical alga Caulerpa taxifolia, on the biodiversity of the Mediterranean marine biota. J Mar Biol Assoc UK 76:235-237

Boudouresque CF (1997) Population dynamics of Caulerpa taxifolla in the Mediterranean, including the mechanisms of interspecific competition. In: Séminaire international Dynamique d'espèces marines invasives: application à l'expansion de Caulerpa taxifolia en Méditerranée. Lavoisier publ, Paris, p 145-162

Boudouresque CF, Lemée R, Mari X, Meinesz A (1996) The invasive alga Caulerpa taxifolia is not a suitable diet for the sea-urchin Paracentrotus lividus. Aquat Bot 53: $245-250$

Carlton JT (1996) Pattern, process, and prediction in marine invasion ecology. Biol Conserv 78:97-106

Carlton JT, Geller JB (1993) Ecologıcal roulette: the global transport of nonindigenous marine organisms. Science $261: 78-82$

Chisholm JRM, Dauga C, Ageron E, Grimont PAD, Jaubert JM (1996) 'Roots' in mixotrophic algae. Nature 381:382

Chisholm JRM, Jaubert JM (1997) Photoautotrophic metabolism of Caulerpa taxifolia (Chlorophyta) in the NW Mediterranean. Mar Ecol Prog Ser 153:113-123

Chisholm JRM, Jaubert JM, Giaccone G (1995) Caulerpa taxifolia in the northwest Mediterranean: introduced species or migrant from the Red Sea? CR Acad Sci Paris Life Sci 318:1219-1226

Coppejans E, Prud'homme van Reine WF (1992) Seaweeds of the Snellius II expedition (E. Indonesia): the genus Caulerpa (Chlorophyta - Caulerpales). Bull Séances Acad R Sci Outre-Mer 37:667-712

Delgado O, Rodriguez-Prieto C, Gacia E, Ballesteros E (1996) lack of severe nutrient limitation in Caulerpa taxifolia (Vahl) C. Agardh, an introduced seaweed spreading over the oligotrophic northwestern Mediterranean. Bot Mar 39: $61-67$

Felsenstein J (1988) Phylogenies from molecular sequences: inference and reliability. Annu Rev Genet 22:521-565

Galtier N, Gouy M (1996) SEAVIEW and PHYLO_WIN: two graphic tools for sequence alignment and molecular phylogeny. Comput Appl Biosci 12:543-548

Gillespie RD, Meinesz A. Critchley AT (1997) Growth responses of Caulerpa taxifolia (Ulvophyceae, Chlorophyta) from the South African aquarist trade. A potential invasive of South African coastal waters. S Afr J Bot 63(6): $480-483$

Guerriero A, Marchetti F, D'Ambrosio M, Senesi S, Dini F, Pietra F (1993) New ecotoxicologically and biogenetically relevant terpenes of the tropical green alga Caulerpa taxifolia which is invading the Mediterranean. Helv Chim
Acta $76: 855-864$

Hillis DM, Moritz C, Porter CA, Bakker RJ (1991) Evidence for biased gene conversion in concerted evolution of ribosomal DNA. Science 251(4991):308-310

Komatsu T, Meinesz A, Buckles D (1997) Temperature and light responses of alga Caulerpa taxifolia introduced into the Mediterranean Sea. Mar Ecol Prog Ser 146:145-153

Larsen N, Olsen GJ, Maidak BL, Mc Caughey MJ, Overbeek R, Macke TJ, Marsh TL, Woese CR (1993) The ribosomal database project. Nucleic Acids Res 21:3021-3023

Lemée R, Boudouresque CF, Gobert J, Malestroit P, Mari X, Meinesz A, Menager V, Ruitton S (1996) Feeding behavjour of Paracentrotus lividus in the presence of Caulerpa taxifolia introduced in the Mediterranean. Oceanol Acta 19(3-4):245-253

Leskinen E. Pamilo P (1997) Evolution of the ITS sequences of ribosomal DNA in Enteromorpha (Chlorophyceae). Hereditas 126(1):17-23

Linares AR, Bowen T, Dover GA (1994) Aspects of nonrandom turnover involved in the concerted evolution of intergenic spacers within the ribosomal DNA of Drosophila melanogaster. J Mol Evol 39(2):151-159

Meinesz A, Benichou L, Blachier J, Komatsu T, Lemée R, Molenaar H, Mari X (1995) Variations in the structure, morphology and biomass of Caulerpa taxifolia in the Mediterranean Sea. Bot Mar 38:499-508

Meinesz A, Boudouresque CF (1996) Sur l'origine de Caulerpa taxifolia en Méditerranée. CR Acad Sci Paris Life Sci 319:603-613

Meinesz A, Cottalorda JM, Chiaverini D, Braun M, Carvalho $N$, Febvre M, Ierardi S, Mangialajo L, Passeron-Seitre G, Thibaut $T$, de Vaugelas J (1997) Suivi de l'expansion de l'algue tropicale Caulerpa taxifolia en Méditerranée: situation au 31 décembre 1996. Université de Nice SophraAntipolis, GIS Posidonie Publisher, Marseille, 1-189

Meinesz A, Hesse B (1991) Introduction et invasion de l'algue tropicale Caulerpa taxifolia en Méditerranée nord-occidentale. Oceanol Acta 14(4):415-426

Meinesz A, Pietkiewicz D, Komatsu T, Caye G, Blachier J, Lemée R, Renoux-Meunier A (1994) Notes taxonomiques préliminaires sur Caulerpa taxifolia et Caulerpa mexicana. In: Boudouresque CF, Meinesz A, Gravez V (eds) First international workshop on Caulerpa taxifolia. GIS Posidonie publications, Marseille, p 105-114

Olsen GJ, Matsuda H, Hagstrom R, Overbeek R (1994) Fast DNAml: a tool for construction of phylogenetics trees of DNA sequences using maximum likelihood. Computer Appl Biosci 10:41-48

Pesando D, Lemée R, Ferrua C, Amade P, Girard JP (1996) Effects of caulerpenyne, the major toxin from Caulerpa taxifolia on mechanisms related to sea urchin egg cleavage. Aquat Toxicol 35:139-155

Plllman A, Woolcott GW, Olsen JL, Stam WT, King JR (1997) Inter- and intraspecific genetic variations in Caulerpa (Chlorophyta) based on nuclear rDNA ITS sequences. Eur J Phycol 32:379-386

Ribera MA, Boudouresque CF (1995) Introduced marine plants, with special reference to macroalgae: mechanisms and impact. In: Round FE, Chapman DJ (eds) Progress in phycological research, Vol 11. Biopress Ltd, Bristol, p $187-268$

Russell DJ (1992) The ecological invasion of Hawaiian reefs by two marine red algae, Acanthophora spicifera (Vahl) Boerg. and Hypnea musciformis (Wulfen) J. Ag., and their association with two native species, Laurencia nidifica J. Ag. and Hypnea cervicornis J. Ag. ICES Mar Sci Symp 194:110-125 
Saitou N, Nei M (1987) The neighbor-joining method: a new method for reconstructing phylogenetic trees. Mol Biol Evol 4:406-425

Sant N, Delgado O, Rodríguez-Prieto C, Ballesteros E (1996) The spreading of the introduced seaweed Caulerpa taxifolia (Vahl) C. Agardh in the Mediterranean Sea: testing the boat transportation hypothesis. Bot Mar 39:427-430

Schlotterer C. Tautz D (1994) Chromosomal homogeneity of Drosophila ribosomal DNA arrays suggests intrachromosomal exchanges drive concerted evolution. Current Biol 4(9):777-783

Swofford DL (1993) PAUP: phylogenetic analysis using parsi-

Editorial responsibility: Otto Kinne (Editor),

Oldendorf/Luhe, Germany mony, version 3.1. Illinois Natural History Survey, Champaign, IL

Taylor WR (1977) Marine algae of the Vega 1965 expedition in the western Pacific ocean. Atoll Res Bull 209:1-16

Verlaque M. Fritayre P (1994) Modifications des communautés algales méditerranéennes en présence de l'algue envahissante Caulerpa taxifolia (Vahl) C. Agardh. Oceanol Acta 17(6):659-672

Villèle X de, Verlaque $M$ (1995) Changes and degradation in a Posidonia oceanica bed invaded by the introduced tropical alga Caulerpa taxifolia in the North Western Mediterranean. Bot Mar 38:79-87

Submitted: May 29, 1998; Accepted: September 8, 1998 Proofs received from author(s): September 23, 1998 